\title{
Transgenic trees and forestry biosafety
}

\author{
Sofía Valenzuela* \\ Centro de Biotecnología \\ Facultad de Ciencias Forestales \\ Universidad de Concepción \\ Casilla 160-C \\ Concepción, Chile \\ Tel: 5641204697 \\ Fax: 5641255164 \\ E-mail: sofvalen@udec.cl \\ Claudio Balocchi \\ Bioforest S.A. \\ Camino a Coronel Km. 15 \\ Concepción, Chile \\ Tel: 5641390438 \\ E-mail: cbalocch@arauco.cl

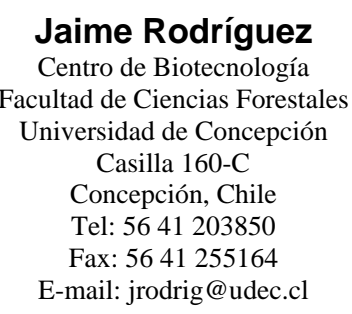

Keywords: biosafety, forestry biotechnology, GMOs, GM trees.

Abbreviations: GM: genetically modified

GMO: genetically modified organism

The benefits from the development of transgenic trees are expected from the improvement of traits as growth and form, wood quality, industrial processes, disease and insect resistance, herbicide tolerance, ecological restoration, rooting ability, etc. One of the first reported field trials with genetically modified forest trees was established in Belgium in 1988 and the characteristic evaluated was herbicide tolerance in poplars. Since then, there have been more than 200 reported trials, involving at least $\mathbf{1 5}$ forest species. The majority of the field trials have been carried out in the USA (64\%). More than $50 \%$ of the field trials are done with Populus species and the main target traits are herbicide tolerance $(31 \%)$, followed by marker genes $(23 \%)$ and insect resistance $(14 \%)$. Until today, there is only one report on commercial-scale production of transgenic forest trees which is Populus nigra with the Bt gene release in China in 2002 and established on commercial plantations in 2003. Operational application of GMO's in forestry depends on technical, economical, political and public aspects, but the development of adequate regulatory frameworks and public acceptance of transgenic trees will define the future of this technology in forestry.

The high demand for wood in the world, requires that in a short term the area of forest plantations be increased (Fenning and Gershenzon, 2002). In comparison to agricultural crops, trees planted for wood production are undomesticated plants. As in agriculture, based on genetic theory and experience, trees have enormous genetic potential that could be expressed in valuable new varieties (Burley, 2001). A way to achieve this is the use of transgenic trees, which could in a same area of land produce more wood and with less environmental impact (Peña and Seguin, 2001). For the world to be supplied with the wood on a long-term sustainable basis, it needs to invest much more in the development of high-yielding, short rotation plantation forests. Biotechnology is essential to achieving this goal. The alternative is that the world's remaining natural forests will continue to be degraded, probably at an accelerating rate, and/or pollution from wood substitutes will increase.

* Corresponding author 


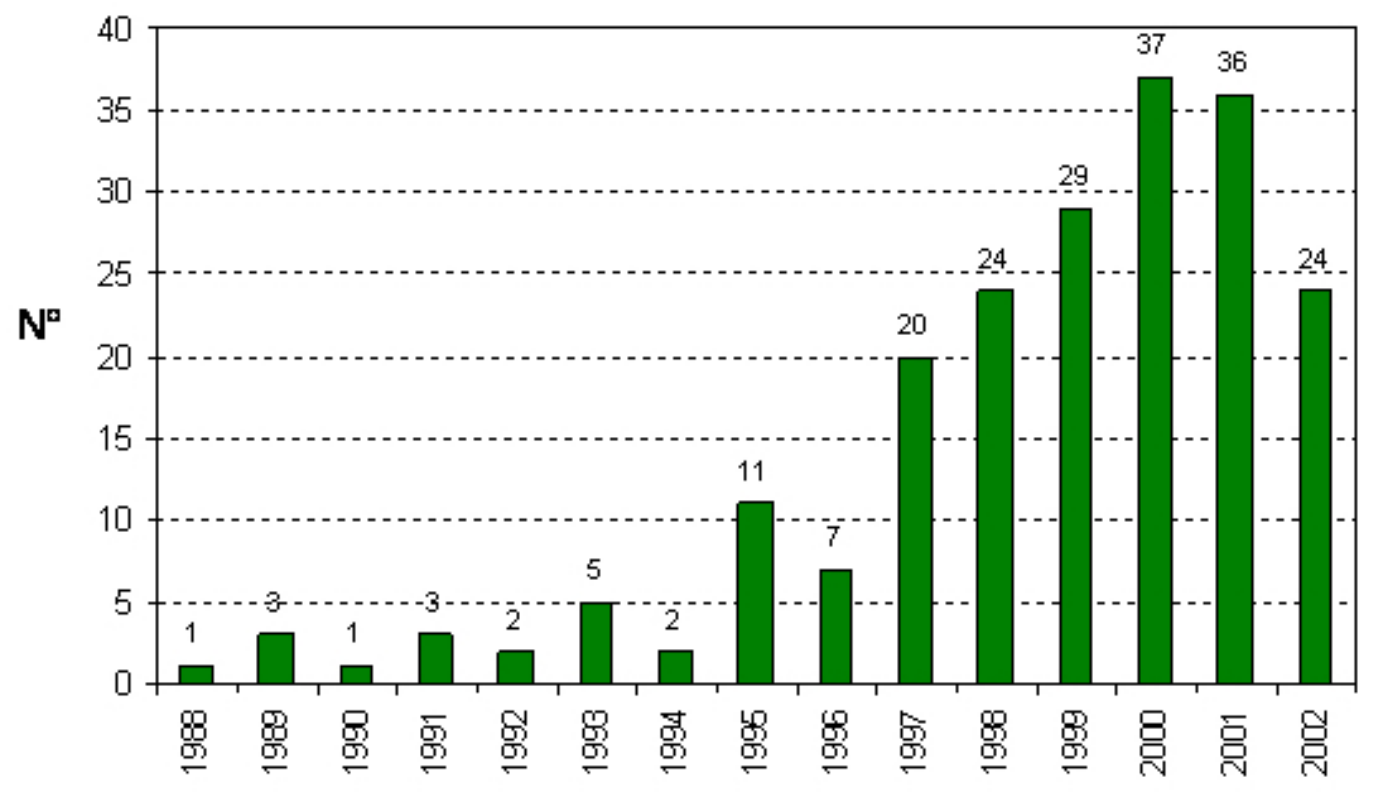

Figure 1. Number of GM trees in field trials per year, 1988-2002. (Data obtained from web pages shown in Annex 1).

The development of genetically modified trees has increased in the last years, having more than 200 field trials involving at least 15 forest species. The main characteristics used have been herbicide tolerance and marker genes. The environmental gains, could be huge, according to Sedjo (2004), it could be US\$ 152 million per year only in the USA, just by the reduced use of pesticides and herbicides. Despite the potential benefits, such as new pest management strategies, ecological restoration, carbon sequestration, among others (Mathews and Campbell, 2000). The use of transgenic trees is not yet a massive practice, and will not be at least in the coming years. For this technology to be affordable (cost-effective), reliable massive micropropagation systems are needed, which are still under study. As well it will depend on social, economical and political factors (Wolfenbarger and Phifer, 2000). In the present work a review of the development of GM trees and their potential risk to the environment are described.

\section{GENETIC TRANSFORMATION IN TREES}

The United States has the largest number of field trials of GM trees, with $64 \%$ of the world's total. In Europe, France is in the first place followed by Finland. Most of the species in field trials are hardwoods (77\%). The main characteristics which are under study, correspond to those related with wood chemistry. Among these the reduction of the proportion of juvenile wood, increase of wood density, reduction of lignin content, modifying the type of lignin and increasing cellulose content can be mentioned (Balocchi and Valenzuela, 2004). In Figure 1, the number of field assays with GM trees during the last 15 years is shown.

As far as institutions involved in the development of GMtrees, Universities do most of the research and currently only a few companies have research projects related with transgenic trees. At a commercial level, there are only two cases of GM trees, which have been released. The first one is the GM papaya, done in Hawaii, in 1997 and the second one corresponds to transgenic Populus in China, which was released in 2002 and established on the field in 2003. Currently, there are at least two other species, which might be released in the short term in China (Clayton, 2005).

Most of the species represented on the field trials are hardwoods (77\%), with Populus being the most used, accounting for $55 \%$ of the field trials. Softwoods represent $23 \%$ of the field trials, with pines being the most important, they represent $15 \%$ of the trials (Figure 2). The most common trait studied on field trials with GM forest trees is herbicide tolerance, with 65 trials (31\%). On the other side, $23 \%$ of the field trials are established just to evaluate the transformation method, employing a marker gene. Other important traits are insect and disease resistance, reproduction biology (sterility) and lignin reduction and modification.

There are still main technical limitations for the use of GM forest trees as stability of transformations; stability of the gene and stability of the effect (promoters), localization and number of copies, expression organ specific, sterility of the GMO's, propagation (embryogenesis - organogenesis) and genetic development. Even if all technical limitations to produce transgenic forest trees are solved, the operational implementation will be limited by economical restrictions 
because most of the genes and processes are covered by patents.

Today, the cost of covering all the royalties involved in the use of a transgenic forest trees in most cases are unknown. On the other side, because the benefits of the transformation, in most traits will be known at the end of the rotation, the definition of the value of the royalties will be difficult and is one of the main limitations to calculate the return on the investment of this technology on the forest companies (Doering, 2004).

\section{RELEASE OF GM-TREES}

There are serious concerns regarding the introduction of GM trees into the environment, especially when related with traits which can give a better fitness, as high-growth and pest and disease resistance. Until date there are no risk assessment studies which can predict with any certainty the impact of releasing GM trees on native biodiversity, which differs with studies done with crops (Wolfenbarger and Phifer, 2000; Snow et al. 2005). The main issue that has been discussed is gene flow, but little research has been done on the impacts that the transgene might have on fitness or other ecological characteristics. Knowledge of gene flow in forest trees is still unsatisfactory due to continued shortcomings of available markers, inherent limitations of statistical models, and the anecdotal nature of many gene flow studies, which are typically limited in scope (Kumar and Fladung, 2001). Another limitation is that pollen gene flow is usually estimated by sampling seeds from a number of mother trees. Restricting sampling to seeds seems adequate when evaluating gene flow in seed collections to be used for artificial reforestation.
Another point is the change in fitness associated with the introduced trait or transgene. In the case of GM-crops, most of the traits introduced are from single genes, like herbicide resistance, insect resistance, etc. In forestry, there are several GM-tree species that are herbicide tolerant, which have already been tested at field trials (Meilan et al. 2002). But also, in the cases of traits with large economical value in forestry, GM-trees will require the introduction (or suppression) of many genes. In most cases, the desired traits as stress tolerance, low lignin levels and others depend on a biochemical pathway and therefore the presence of the trait is related to a gene complex. Going back then to gene flow, it seems more unlikely that all these genes will be "transferred" due to pollen or gene flow in a single event (Strauss et al. 2004).

If GM trees are to be planted in the near future, it will be more likely that they will contain more than one transgen, multigenic (i.e. to low the levels of lignin) or traits (i.e. herbicide tolerance and insect resistance). Therefore it will be more difficult to model the impacts, either direct or indirect, on biodiversity.

\section{BIOSAFETY AND GM TREES}

It is clear that in the case of GM trees used for forest plantations, there is very low risk for human health and food safety. The main concern deals with, on one hand the long rotation time of trees and on the other hand, the little knowledge that there is in tree physiology and genetics. The main issue is the possible "transgene contamination" (gene flow) or that the transgene might be introduced into the genome of a related species, giving it a special fitness.

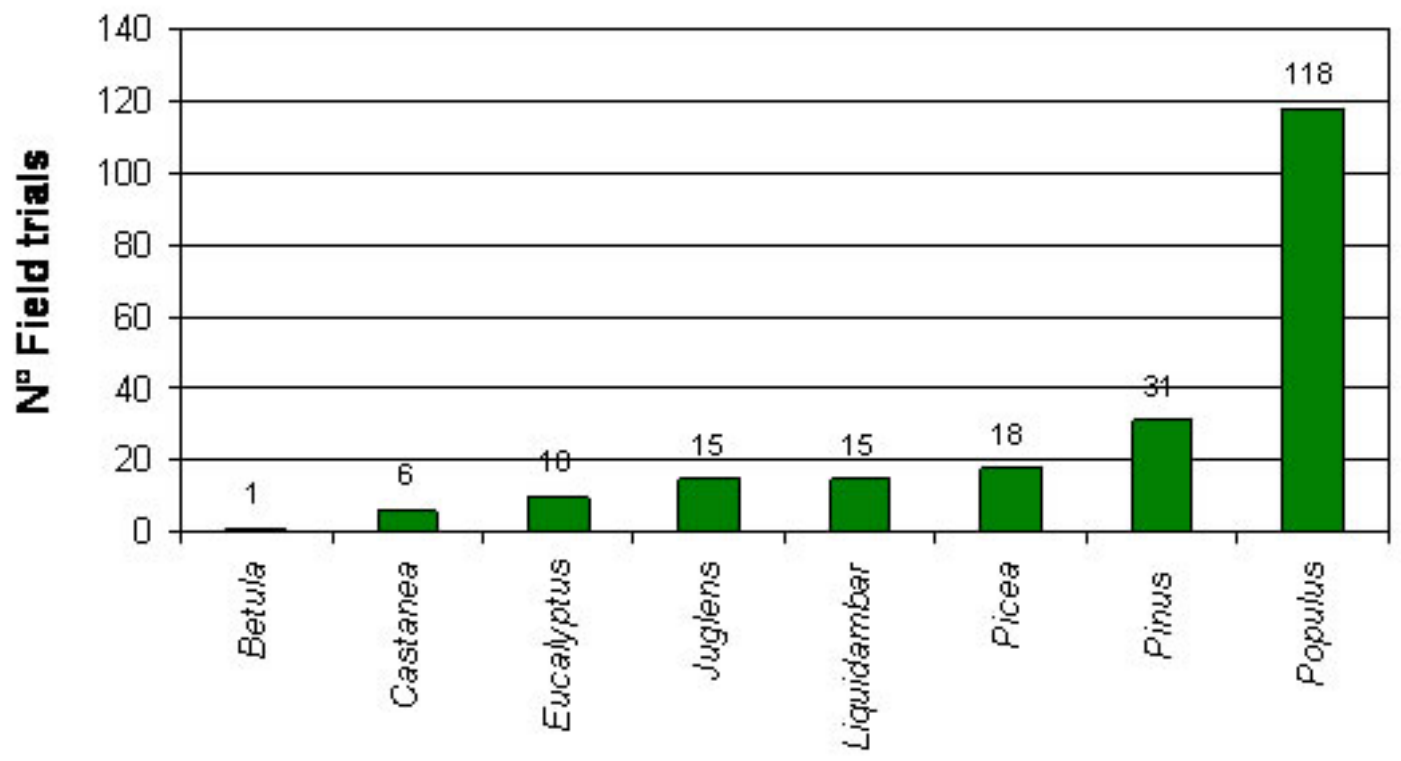

Figure 2. Main tree genus that have been transformed and tested in field trials worldwide. (Data obtained from web pages shown in Annex 1). 
Currently, there is no country that has a specific risk assessment for GM trees, only as mentioned before, experiences in China and Hawaii, in which the risk assessment was carried out in a similar way as the one for GM crops. If this keeps being the case, there will be some problems in the near future, specially in issues related with the inserted gene's stability, since trees stay in the environment for longer time. In the best case scenario, it could take at least some twenty years to study a few generations of short rotation GM trees, which would clearly slow down the research.

GM tree field trials have not been able to last longer than 6 years, due to boycotts of different environmentalists groups and to different types of certification (i.e. Forest Stewardship Council), which forbidden the use of GM trees, even under confined conditions. It might be pointed out, the beneficial aspects of GM trees, as for example in the case of trees which have lower lignin levels, it would mean on one hand, less pressure for the land and native plantations and on the other the use of less amounts of chemical reagents in the process of pulping (Valenzuela and Strauss, 2005).

Therefore it is necessary to find a way in which the risk assessment of GM trees be feasible. With the current systems, it is very difficult to achieve the "high standards" given by the regulatory organizations. In the USA, where GMOs have a good acceptance by the public, the requirements for containment of pollen and seed from trees of commercially relevant sizes, make such essential adaptive research virtually impossible to carry out (Valenzuela and Strauss, 2005).

An alternative to minimize vertical gene flow is the use of sterile GM trees. Much effort has been put doing research and understanding genes involved in the flowering process of trees (Erikson et al. 2000; Fladung, 2004). However this issue raises new concerns, related on the impact on the biodiversity. This is based on that the fewer amounts of flowers could have a negative impact on insects or birds which feed on them.

The use of transgenic trees in the forestry sector, has very different objectives than those used for crops. They are mainly based in improving wood quality, so as to diminish the pressure on the land. The genes involved in these processes are quite specific and are mainly present in trees; therefore its possible escape to the environment does not have a major risk.

The development of GM-trees in the last years has increased drastically, but currently there is no specific and validated system for carrying out a risk assessment for GMtrees. The main concerns are related with gene flow, but the escape of the genes employed nowadays, apparently do not represent an environmental risk. So what can we expect from GE-trees at a commercial level? Probably commercial releases will continue with short rotation species, such as
Populus and Eucalyptus. At the same time, exotic species are more likely to be released, since in most cases they will not have problems with gene flow. Other factor that will regulate what species will be first released at a commercial scale is related with propagation technology to scaling up, in a cheap and fast way, the GE-trees. Therefore species which already have a clonal program established will be the first candidates.

\section{REFERENCES}

BALOCCHI, C. and VALENZUELA, S. Introduction to GMOs and Biosafety in Forestry. In: Proceedings of the Forestry Biotechnology Workshop, Global Biotechnological Forum. (2-5 March, 2004, Concepción, Chile). KELLISON, R.; MCCORD, S. and GARTLAND, K. eds., 2004. p. 85-96. Available from Internet: http://www.forestbiotech.org/pdffiles/ChlePDFfinal31Jan2 005.pdf. ISBN 0-9763838-0-2.

BURLEY, J. Genetics in sustainable forestry: the challenges for forest genetics and tree breeding in the new millennium. Canadian Journal of Forest Research, 2001, vol. 31, no. 4, p. 561-565.

CLAYTON, M. Now, bioengineered trees are taking root. The Christian Science Monitor [online]. 10 March 2005 [10 March 2005]. Available from Internet: http://www.csmonitor.com/2005/0310/p14s02-sten.html.

DOERING, D.S. Will the Marketplace See the Sustainable Forest for the Transgenic Tree? In: STRAUSS, S. and BRADSHAW, H.D. eds. The Bioengineered Forest: challenges for Science and Society. 2004. p. 112-140.

ERIKSON, M.E.; ISRAELSSON, M.; OLSSON, O. and MORITZ, T. Increased giberellin biosynthesis in transgenic trees promotes growth biomass production and xylem fiber length. Nature Biotechnology, 2000, vol. 18, no. 7, p. 784788.

FENNING, T. and GERSHENZON, J. Where will the wood come from? Plantation forests and the role of biotechnology. Trends in Biotechnology Sciences, 2002, vol. 20, no. 7, p. 291-296.

FLADUNG, M. Gene technology and proteomics. In: Proceedings of the Forestry Biotechnology Workshop, Global Biotechnological Forum. (2-5 March, 2004, Concepción, Chile). KELLISON, R.; MCCORD, S. and GARTLAND, K. eds., 2004. p. 85-96. Available from Internet:

http://www.forestbiotech.org/pdffiles/ChlePDFfinal31Jan2 005.pdf. ISBN 0-9763838-0-2.

KUMAR, S. and FLADUNG, M. Controlling transgene integration in plants. Trends in Plant Science, 2001, vol. 6, no. 4, p. 155-159. 
MATHEWS, J.M. and CAMPBELL, M.M. The advantages and disadvantages of the application of genetic engineering to forest trees: a discussion. Forestry, 2000, vol. 73, no. 4, p. 372-380.

MEILAN, R.; AUERBACH, D.J.; MA, C.; DIFAZIO, S.P. and STRAUSS, S. Stability of herbicide resistance and GUS expression in transgenic hybrid poplars (Populus spp.) during several years of field trials and vegetative propagation. HortScience, 2002, vol. 37, no. 2, p. 277-280.

PEÑA, L. and SÉGUIN, A. Recent advances in the genetic transformation of trees. Trends in Biotechnology, 2001, vol. 19, no. 12, p. 500-506.

SEDJO, R. Biotechnology and the Global World Supply. In: STRAUSS, S. and BRADSHAW, H.D., eds. The Bioengineered Forest. Challenges for Science and Society.
2004, p. 23.

SNOW, A.; ANDOW, D.A. and GEPTS, P. Genetically engineered organisms and the environment: Current status and recommendations. Ecological Applications, 2005, vol. 15, no. 2, p. 377-404.

STRAUSS, S.; BRUNNER, A.; BUSOV, V.; MA, C. and MEILAN, R. Ten lessons from 15 years of transgenic Populus research. Forestry, 2004, vol. 77, no. 5, p. 455463.

VALENZUELA, S. and STRAUSS, S. Lost in the woods. Nature Biotechnology, 2005, vol. 23, no. 5, p. 531-532.

WOLFENBARGER, L.L. and PHIFER, P.R. The ecological risks and benefits of genetically engineered plants. Science, 2000, vol. 290, no. 5499, p. 2088-2093.

Annex 1: Web Sites for GMO Field Trials.

\begin{tabular}{|c|c|}
\hline Country & WEB SITE \\
\hline Argentina & http://www.sagpya.mecon.gov.ar/ \\
\hline Australia & http://www7.health.gov.au/ogtr/index.htm \\
\hline Austria & http://biotech.jrc.it/deliberate/gmo.asp \\
\hline Belgium & http://biotech.jrc.it/deliberate/gmo.asp \\
\hline Brazil & http://www.ctnbio.gov.br/ \\
\hline Bulgaria & http://binas.unido.org/binas/ \\
\hline Canada & http://www.inspection.gc.ca/english/plaveg/pbo/pbobbve.shtml \\
\hline Denmark & http://biotech.jrc.it/deliberate/gmo.asp \\
\hline Egypt & http://binas.unido.org/binas/ \\
\hline Finaland & http://biotech.jrc.it/deliberate/gmo.asp \\
\hline France & http://biotech.jrc.it/deliberate/gmo.asp \\
\hline Germany & http://www.rki.de/ \\
\hline Greece & http://biotech.jrc.it/deliberate/gmo.asp \\
\hline Hungary & http://biosafety.abc.hu/biosafe_eng.html \\
\hline India & http://binas.unido.org/binas/ \\
\hline Irish Republic & http://biotech.jrc.it/deliberate/gmo.asp \\
\hline Italy & http://biotech.jrc.it/deliberate/gmo.asp \\
\hline Luxembourg & http://biotech.jrc.it/deliberate/gmo.asp \\
\hline México & http://web2.senasica.sagarpa.gob.mx/xportal/sen/qesen/Doc1/ \\
\hline Netherlands & http://biotech.jrc.it/deliberate/gmo.asp \\
\hline New Zealand & http://www.ermanz.govt.nz/ \\
\hline Norway & http://biotech.jrc.it/deliberate/gmo.asp \\
\hline Phillipines & http://binas.unido.org/binas/ \\
\hline Portugal & http://biotech.jrc.it/deliberate/gmo.asp \\
\hline Russian Federation & http://binas.unido.org/binas/ \\
\hline South Africa & http://www.nda.agric.za/ \\
\hline Spain & http://biotech.jrc.it/deliberate/gmo.asp \\
\hline Sweden & http://biotech.jrc.it/deliberate/gmo.asp \\
\hline Thailand & http://biodiversity.biotec.or.th/biosafety/ \\
\hline Ukraine & http://binas.unido.org/binas/ \\
\hline United Kingdom & http://biotech.jrc.it/deliberate/gmo.asp \\
\hline United States & http://www.isb.vt.edu/cfdocs/fieldtests1.cfm \\
\hline
\end{tabular}

